\title{
HEADLINE PATTERNS IN VIRAL WEB CONTENT - ENGLISH-BULGARIAN COMPARATIVE CASE STUDY
}

\author{
Radostina Iglikova*
}

\begin{abstract}
The present article deals with the patterns for creating viral headlines for web content. More specifically, it offers a comparative, corpus-based case study of the patterns employed in English-language and Bulgarian-language viral headlines pertaining to one particular topic (the taste of Coca-Cola at McDonald's). The aim of the article is to provide a descriptive analysis of a specific phenomenon and a comparison of the approaches to creating headlines on English-language websites on the one hand, and on Bulgarian websites, on the other.
\end{abstract}

Key words: headline patterns, web content, virality, Coca-Cola at McDonald's

\section{Introduction}

The first source of information available to users about the content a particular website (or websites, if a search engine is used) offers is indeed the headline. Before they actually reach the content itself and the contents page where it resides, users need to complete a process of selection based only on the "label" of the actual content, i.e., the headline. In other words, users rely on headlines in their process of selection among competing alternatives. As Orendorff (2014 URL) points out, "[T] he headline is the most important element of any page. It isn't just your audience's first impression; sometimes it is their only impression."

Online people "look at headings and subheadings first; they scan for hyperlinks, numerals and keywords" (McGovern et al. 2002: 1). This type of behavior results from the value Web users place on processing the largest possible amounts of content with the least possible effort and for the shortest amount of time possible in an environment so rich in information and potential candidates for their limited time and attention. This emphasizes the potential headlines have to "make or break" user experience - "[O]n the Web, you live or die by your headings (or headlines as they are called in newspapers and magazines). A good one makes it easier for readers to find your article, and much more likely that they will read what you have written" (McGovern et al 2002: 5).

\footnotetext{
* Assistant Prof. PhD at Shumen University, Department of English Studies, Shumen, Bulgaria, e-mail: r.iglikova@shu.bg.
} 


\section{Previous research in the field}

Changes in language use stemming from the way in which people behave (including linguistically) in the context of the World Wide Web have received extensive treatment in the field of writing for the Web (Crystal 2001; McGovern et al. 2002; Morkes, Nielsen 1997; Morville, Rosenfeld 2007; Nielsen 1997, 1998, 2000, 2006, 2007a, 2007b, 2008, 2011a, 2011b, 2012; Redish 2012). These differences arising from the fact that "people behave differently when online" (McGovern et al 2002: 1) are strongly reflected in the nature of web content headlines. Nielsen (1998) points out that the differences between print headlines and online headlines are considerable due to the different way they are utilized in terms of medium, context, user expectations and reading habits.

Similarly, Redish observes that " $[\mathrm{H}]$ eadlines online have to do even more than headlines in print. On paper, you usually see the headline and the article together on the same piece of paper. Online and especially on a mobile, the headline often appears first by itself as a link" (2012: 157).

Furthermore, research in the field of writing for the Web (Krug 2006; Nielsen 2008; Redish 2012; Stolley 2011) emphasizes the importance of following specific guidelines in order to compensate for the "impatience" of web users, the extremely limited resources of time and attention people are generally willing to spend on any particular item of web content.

Thus, an important aspect of ensuring the quality of web headlines and their potential for becoming viral (or, in other words, extremely popular or well known - see Cambridge Dictionary URL) is the existence of patterns for creating headlines with analogous structures. Patterns in headlines serve as templates or models applied in the creation of particular headline occurrences. Firstly, these patterns comprise specific sets of constant elements which build up the basis of the pattern itself. Secondly, they include empty "slots" or positions which are open to be filled by various elements in order to produce specific occurrences or, in this case, headlines following the particular pattern in question. In addition to the constant elements which build it, each pattern contains information about the structural relations among its constant as well as variable constituents.

Morrow (2012: 4) describes the mechanism of headline patterns in the following way:

"If you look carefully at any great headline, you can distill it down to a fillin-the-blank "template" that works for almost every topic in any niche. The best writers I know have thousands of them either saved to a file on their computers or floating around in their heads, where they can reference them at a moment's notice to develop a winning headline of their own."

In addition, these blank "templates" or patterns can be organized into several categories. Morrow (2012: 6-8) offers the following classification: 
- Threat Headlines - focusing on people's fears and apprehensions;

- Zen Headlines - promising users a solution to a problem or a (number of) way(s) to make their life easier;

- Piggyback Headlines - relying on the reputation of a famous person/ organization etc.;

- Mistake Headlines - focusing on possible mistakes people are likely to make in certain situations;

- How to Headlines - offering practical tips and instructions;

- List Headlines - promising a specific number of options for readers to consider/ choose from.

A different headline classification proposed by Bly (2005: 22-25) includes the following eight basic types:

- Direct Headlines - "state the selling proposition directly, with no wordplay, hidden meanings, or puns";

- Indirect Headlines - "[T]he indirect headline makes its point in a roundabout way. It arouses curiosity, and the questions it raises are answered in the body copy";

- News Headlines - "[I]f you have news about your product, announce it in the headline";

- How-to Headlines - "[H]ow-to headlines offer the promise of solid information, sound advice, and solutions to problems";

- Question Headlines - "[T]o be effective, the question headline must ask a question that the reader can empathize with or would like to see answered... Question headlines should always focus on the reader's self-interest, curiosity, and needs";

- Command Headlines - "the first word in the command headline is a strong verb demanding action on the part of the reader";

- Reason-Why Headlines - signals a "list of ... features"; "Reason-why headlines need not contain the phrase 'reason why.' Other introductory phrases such as '6 ways,' '7 steps,' and 'here's how' can do just as well”;

- Testimonial Headlines - include a quote from a user; "[Q]uotation marks around the headline and the body copy signal the reader that the ad is a testimonial".

Still another classification is featured in a study by Conductor (Safran 2013 URL), which isolates "the five general ways in which headlines are written". These five "high-level headline types" include "Normal" (declarative statement) 
structure, question, "How to" structure, structures featuring a number and, finally, a reader-addressing structure (ibid.). Among these, the numeralcontaining type of structure ranks first in popularity in viral headlines (36 \%) (see fig. 1 below):

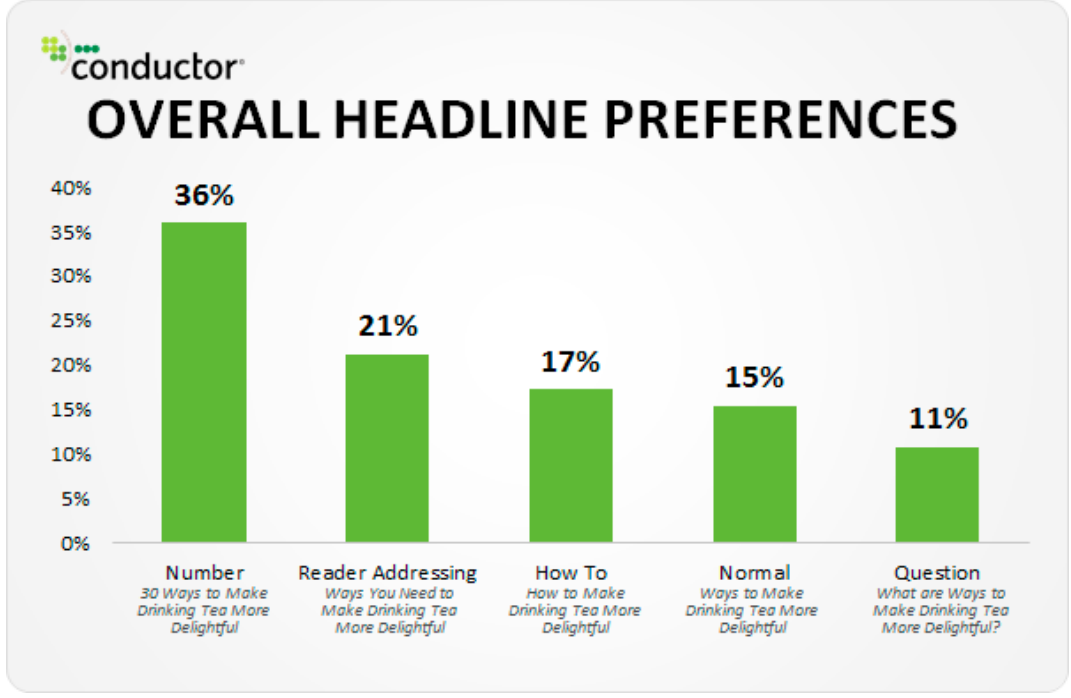

Fig. 1 - Overall headline preferences (Safran 2013 URL)

Viral headlines from both English-language (Buzzfeed.com and Cosmopolitan. com) and Bulgarian-language (Cosmopolitan.bg) websites have also been analyzed in terms of their preference for the use of specific numerals (Iglikova 2016: 203-211). The results based on a corpus of 689 numeral-containing headline occurrences on the aforementioned websites reveal the following top 5 most frequently occurring numerals (see Table 1 below):

\begin{tabular}{|c|c|c|c|}
\hline $\begin{array}{l}\text { RATING } \\
(753 \text { nu- } \\
\text { meral oc- } \\
\text { currences } \\
\text { total) }\end{array}$ & $\begin{array}{c}\text { BUZZFEED/BF } \\
\text { (254 numeral occur- } \\
\text { rences) }\end{array}$ & $\begin{array}{c}\text { COSMOPOLITAN US/ } \\
\text { CUS } \\
\text { (233 numeral occur- } \\
\text { rences) }\end{array}$ & $\begin{array}{l}\text { COSMOPOLITAN } \\
\text { BULGARIA/CBG } \\
\text { (266 numeral occur- } \\
\text { rences) }\end{array}$ \\
\hline 1. & $\begin{array}{l}21-8.66 \% / 22 \text { oc- } \\
\text { currences } \\
\text { In CUS: } 0.86 \% / 2 \text { oc- } \\
\text { currences } \\
\text { In CBG: } 0.75 \% / 2 \text { oc- } \\
\text { currences }\end{array}$ & $\begin{array}{l}10-9.87 \% / 23 \text { occur- } \\
\text { rences } \\
\text { In BF: } 3.94 \% / 10 \text { occur- } \\
\text { rences } \\
\text { In CBG: } 16.92 \% / 45 \text { oc- } \\
\text { currences }\end{array}$ & $\begin{array}{l}10-16.92 \% / 45 \text { oc- } \\
\text { currences } \\
\text { In BF: } 3.94 \% / 10 \text { oc- } \\
\text { currences } \\
\begin{array}{l}\text { In CUS: } 9.87 \% / 23 \text { oc- } \\
\text { currences }\end{array}\end{array}$ \\
\hline
\end{tabular}




\begin{tabular}{|c|c|c|c|}
\hline $\begin{array}{l}\text { RATING } \\
\text { (753 nu- } \\
\text { meral oc- } \\
\text { currences } \\
\text { total) }\end{array}$ & $\begin{array}{c}\text { BUZZFEED/BF } \\
\text { (254 numeral occur- } \\
\text { rences) }\end{array}$ & $\begin{array}{l}\text { COSMOPOLITAN US/ } \\
\text { CUS } \\
\text { (233 numeral occur- } \\
\text { rences) }\end{array}$ & $\begin{array}{l}\text { COSMOPOLITAN } \\
\text { BULGARIA/CBG } \\
\text { (266 numeral occur- } \\
\text { rences) }\end{array}$ \\
\hline 2. & $\begin{array}{l}18-7.48 \% / 19 \text { occur- } \\
\text { rences } \\
\text { In CUS: } 0.43 \% / 1 \text { oc- } \\
\text { currence } \\
\text { In CBG: } 0\end{array}$ & $\begin{array}{l}11-9.01 \% / 21 \text { occur- } \\
\text { rences } \\
\text { In BF: } 1.57 \% \text { / } 4 \text { occur- } \\
\text { rences } \\
\text { In CBG: } 1.88 \% / 5 \text { oc- } \\
\text { currences }\end{array}$ & $\begin{array}{l}5-13.91 \% / 37 \text { occur- } \\
\text { rences } \\
\text { In BF: } 0.39 \% / 1 \text { oc- } \\
\text { currence } \\
\text { In CUS: } 3.43 \% / 8 \text { oc- } \\
\text { currences }\end{array}$ \\
\hline 3. & $\begin{array}{l}15-6.3 \% / 16 \text { occur- } \\
\text { rences } \\
\text { In CUS: } 3.43 \% / 8 \text { oc- } \\
\text { currences } \\
\text { In CBG: } 4.51 \% / 12 \\
\text { occurrences }\end{array}$ & $\begin{array}{l}12-8.15 \% / 19 \text { occur- } \\
\text { rences } \\
\text { In BF: } 3.94 \% / 10 \text { occur- } \\
\text { rences } \\
\text { In CBG: } 2.63 \% / 7 \text { oc- } \\
\text { currences }\end{array}$ & $\begin{array}{l}7-13.53 \% / 36 \text { occur- } \\
\text { rences } \\
\text { In BF: } 3.15 \% / 8 \text { occur- } \\
\text { rences } \\
\text { In CUS: } 3.00 \% / 7 \text { oc- } \\
\text { currences }\end{array}$ \\
\hline 4. & $\begin{array}{l}22-5.51 \% / 14 \text { occur- } \\
\text { rences } \\
\text { In CUS: } 1.29 \% / 3 \text { oc- } \\
\text { currences } \\
\text { In CBG: } 0.75 \% / 2 \text { oc- } \\
\text { currences }\end{array}$ & $\begin{array}{l}13-6.87 \% / 16 \text { occur- } \\
\text { rences } \\
\text { In BF: } 3.54 \% / 9 \text { occur- } \\
\text { rences } \\
\text { In CBG: } 1.88 \% / 5 \text { oc- } \\
\text { currences }\end{array}$ & $\begin{array}{l}8-9.77 \% / 26 \text { occur- } \\
\text { rences } \\
\text { In BF: } 1.97 \% / 5 \text { occur- } \\
\text { rences } \\
\text { In CUS: } 3.00 \% / 7 \text { oc- } \\
\text { currences }\end{array}$ \\
\hline 5. & $\begin{array}{l}17-5.12 \% / 13 \text { occur- } \\
\text { rences } \\
\text { In CUS: } 2.15 \% / 5 \text { oc- } \\
\text { currences } \\
\text { In CBG: } 0.38 \% / 1 \text { oc- } \\
\text { currence } \\
27-5.12 \% / 13 \text { occur- } \\
\text { rences } \\
\text { In CUS: } 0 \\
\text { In CBG: } 0\end{array}$ & $\begin{array}{l}14-4.72 \% / 11 \text { occur- } \\
\text { rences } \\
\text { In BF: } 0.79 \% / 2 \text { occur- } \\
\text { rences } \\
\text { In CBG: } 3.38 \% / 9 \text { oc- } \\
\text { currences }\end{array}$ & $\begin{array}{l}6-7.89 \% / 21 \text { occur- } \\
\text { rences } \\
\text { In BF: } 0.39 \% / 1 \text { oc- } \\
\text { currence } \\
\text { In CUS: } 2.58 \% / 6 \text { oc- } \\
\text { currences }\end{array}$ \\
\hline
\end{tabular}

Table 1 - Correlation of top 5 most frequently occurring numerals on BuzzFeed (BF), Cosmopolitan US (CUS) and Cosmopolitan Bulgaria (CBG) 


\section{a. Research questions}

The present article offers a discussion of the following research questions:

- What types of headlines have been used overall (based on the classifications proposed by Morrow (2012: 6-8), Bly (2005: 22-25) and Safran (2013 URL);

- What patterns for creating headlines can be observed and which are the most popular ones;

- Do the preferred types of headlines and patterns for their creation correspond to the preferred types revealed in previous research;

- Which numerals have been used in the headlines and do they correspond to the preferred ones from previous research;

- Do the English-language headlines use the same preferred patterns as the Bulgarian-language ones.

\section{Methods}

In researching the aforementioned questions, the present article employs the following methodological framework:

- Web-based corpus-analytical approach ("Web for corpus", Hundt et al 2007: 1-6) - for the purposes of the analysis has been compiled a custom-made corpus of 59 viral web headlines from different websites;

- contrastive approach - by analyzing corpus materials from two different languages the study attempts to provide a cross-linguistic and contrastive perspective;

- descriptive approach as opposed to a theory-building one - the study does not aim at creating a new theoretical approach, but rather applies the existing classifications to the data;

- qualitative analysis of relevant quantitative results - instead of neglecting either of these two aspects of research, the study attempts to combine elements of each; the emphasis, however, remains on providing qualitative analysis of the registered phenomena.

As a result of the adopted approach, the article has its limitations in that it does not claim that the results have absolute statistical value. Instead, it aims at describing the particular choices different websites make in employing patterns for creating viral headlines pertaining to one and the same topic, as well as attempts to provide a cross-linguistic, comparative aspect to the research topic. 


\section{Data analysis}

The corpus includes all headlines published on the topic of "Coca-Cola at McDonald's" in the period between October, 2016 and April, 2017 and comprises 55 English-language and 4 Bulgarian-language headlines. The headlines are published by a 59 different websites for viral content, some of the most popular among them being: www.cosmopolitan.com, www.thesun.co.uk, www. foxnews.com, www.glamour.com, www.mirror.co.uk, www.quora.com, www. unilad.co.uk, www.ladbible.com, www.viralthread.com, www.yahoo.com, www.cookingpanda.com and www.blitz.bg.

Although they do not fall within the scope of the present study, the formatting and spelling of the headlines have been preserved in order for the corpus to remain usable for possible future studies in these areas.

The analysis and classification of the headlines based on the aforementioned categories and types of headline have yielded the following patterns:

- Piggyback, reason-why headline structured as a declarative statement (the so-called "normal" type according to the aforementioned research by Saffran). These include the following examples:

"The secret reason why a McDonald's Coke tastes the best"

"The Real Reason Why McDonald's Coke Tastes So Good"

"Here's Why McDonald's Coke Tastes Better"

"There's a reason McDonald's Coca-Cola tastes different"

"This is why the Coke at McDonalds (sic) tastes so much better than at other fast food restaurants"

"This is the reason McDonald's Coke tastes BETTER than any other"

“Coke Really Does Taste Better At McDonald's, And Here's Why"

"Secret to why McDonald's Coke Tastes Best"

"So THIS Is Why Coca-Cola From McDonald's Tastes So Good"

“HERE'S WHY MCDONALD'S COCA-COLA TASTES SO GREAT"

“There's A Reason Why McDonald's Coca-Cola Tastes Better"

"This Is Why McDonald's Coke Tastes Better Than All Other Coke"

"FINALLY! THE REASON MCDONALDS COKE TASTES BETTER THAN EVERY OTHER FAST FOOD CHAIN"

"There's a reason why Coca-Cola tastes nicer from McDonald's than in other restaurants" 
"This is Why McDonald's Coca-Cola Tastes So Good"

"McDonald's Coke Really Does Taste Better, and Here's Why"

"Here's Why The Coca-Cola in McDonalds (sic) Tastes So Good"

"This Is Why Coca Cola Tastes Better From McDonalds (sic)"

“There's A Reason Coke From McDonald's Tastes Better Than All The Others"

"The secret of why McDonald's Coke tastes better than any other has been revealed"

"McDonald's Shares the Impressive Reasons Its Coke Tastes So Effing Good"

“There's A Reason Coke From McDonald's Tastes Better Than All The Others"

"Coca-Cola tastes better at McDonald's - and this is why"

"This is Why McDonald's Coca-Cola Tastes So Good"

"This Is Why Coke Tastes Better At McDonald's"

“THE REAL REASON WHY MCDONALD'S COCA-COLA TASTES BETTER" (3 different sources)

“THE AMAZING REASON WHY MCDONALD'S COKE TASTES SO GOOD..."

"Coke Really Does Taste Better at McDonald's, and Here's Why"

"The Real Reason Why McDonald's Coke Tastes So Good"

"McDonald's Has The Best Coke: Here's Why"

"Истинската причина Кока Кола в Макдоналдс да е с по-добър вкус от обикновената Кока Кола" (literally, "The real reason for Coca-Cola in McDonald's to have a better taste than regular Coca-Cola", translation mine)

"Разкриха тайната защо Кока Кола в Макдоналдс е с по-добър вкус от обикновената" (literally, "[They] revealed the secret why Coca-Cola in McDonald's has a better taste than the regular [one]", translation mine)

- Piggyback, reason-why headline structured as a question, either direct (with actual interrogative word order and/or punctuation) or indirect (containing an initial "why" but preserving declarative word order and lacking a question mark). These include the following examples:

"Why does Coca-Cola taste different at McDonald's?" 
"Why does Coca Cola taste better at McDonald's than anywhere else?"

"Why does the Coca-Cola taste better at McDonald's than regular CocaCola?"

"Why Does The Coke At McDonald's Taste So Good?" (2 different sources)

"Why Does McDonald's Coke Taste So Good?"

"Why McDonald's Coke Tastes Better?"

"Why does McDonalds coke taste better and how does it help them to win the competition in an oligopoly of fast food industry?"

“Защо колата на МакДоналдс е толкова вкусна?" (literally, "Why is the McDonald's Coke so tasty?", translation mine)

"Why McDonald's Coke is better aka The real reason McDonald's Coke tastes so good"

"Why McDonald's Coke Really Does Taste Better"

“WHY COCA-COLA TASTES 'BETTER' IN MCDONALD'S"

"Коя е причината колата на McDonald's да е толкова вкусна" (literally, "What is the reason for the McDonald's Coke to be so tasty", translation mine)

- Piggyback, reason-why headline addressing the reader. This pattern either includes the personal pronoun "you" to refer exophorically to the reader in the form of a question, or is structured according to the question pattern without an explicit subject. Here can be included the following examples:

“DID YOU KNOW THERE'S A REASON MCDONALD'S COKE TASTES BETTER?”

"THIRSTY FOR ANSWERS? This is why McDonald's Coke tastes better than every other fast food chain"

"Did You Know There's A Reason McDonald's Coke Tastes Better?"

"Did You Know There's A Reason Why McDonald's Coke Tastes So Much Better? Here's Why"

"If You Think The Coca Cola Tastes Better At McDonald's You're Not Wrong, And Here's The Reason Why"

- Piggyback, reason-why headline which contains a number/ offers a list. This type of pattern is always structured declaratively. Here can be grouped the following examples: 
"6 Reasons Why Coca-Cola Tastes Better at McDonald's"

"6 Reasons McDonald's Coke Tastes Better Than Competitors"

“Three Reasons Why Coke Tastes Better At McDonald's"

"The Four Reasons Why McDonald's Soda Tastes Better Than Soda From Anywhere Else"

"Reasons Why Coca-Cola Tastes Better at McDonald's"

\section{Results/ Key findings}

The results from the analysis reveal a tendency for the employment of a limited number of headline types - namely, piggy-back, reason-why headlines which can be one of the following - declarative statements, direct/indirect questions, reader-addressing, using a numeral/listing. Within each of the headline types there can be observed the application of a limited set of patterns providing empty slots or positions to be filled in different ways. Based on the specific ways these empty slots within each basic pattern are filled there can be isolated further variations.

Depending on whether the headline is formulated as a declarative statement, a direct/indirect question, as addressing the reader or as offering a list, it can contain a different number of slots or positions to be filled. One of the main slots is the one dedicated to introducing the existence of a reason or a number of reasons (hence the reason-why classification), while another slot contains reference to the way Coca-Cola at McDonald's tastes (hence the piggy-back classification). The second slot is present in every headline, regardless of the specific subtype, while the first one can be either replaced by "why" (the second element of the reason-why relationship) in direct/indirect question headlines, introduced by a "Did you know..." in reader-addressing headlines or, finally, preceded by a numeral in listing headlines.

The slot introducing the reason-why element can therefore offer the following patterns where each of the italicized elements provides an option for varying this part of the headline by filling in the slot with a different word:

"The secret/real/amazing reason"

"This is the/Here is the/There is a reason"

“Истинската причина" (literally, “The real reason”, translation mine)

The slot referring to the way Coca-Cola tastes at McDonald's similarly offers a number of pattern variations based on the slots it provides: 
"Coca-Cola/Coke in/at/from McDonald's tastes better/so good/the best/ different than anywhere else/regular Coca-Cola"

“колата на МакДоналдс/колата на McDonald's/Кока Кола в Макдоналдс е толкова вкусна/с по-добър вкус от обикновената Кока Кола" (literally, "The McDonald's coke/Coca-Cola in McDonald's is so tasty/has a better taste than regular Coca-Cola", translation mine)

In addition, there can be observed a tendency for websites to combine several types of headlines into one, which yields more diverse results. Thus in all 59 occurrences we have a basic piggyback, reason-why type of headline which has been combined with a particular type of syntactic structure - a statement or a direct/indirect question. Only on one occasions has there been used a structure which deviates from these two main types - namely, the use of a conditional mood in "If You Think The Coca Cola Tastes Better At McDonald's You're Not Wrong, And Here's The Reason Why".

The most common combination of headline types includes the use of a direct question addressing the reader either explicitly (where the reader is exophorically referred to by means of the personal pronoun "you" - "Did You Know There's A Reason McDonald's Coke Tastes Better?") or implicitly (a question where the addressee is implicit, such as "Why does Coca-Cola taste different at McDonald's?"). An interesting detail concerning the use of questions in headlines is also the definitive preference for direct questions over indirect ones - out of 12 question headlines, 8 are of the direct kind (such as “Защо колата на МакДоналдс е толкова вкусна?”/“Why is the McDonald’s Coke so tasty?") and only 4 of the indirect kind ("Коя е причината колата на McDonald's да е толкова вкусна"/“What is the reason for the McDonald's Coke to be so tasty").

An interesting aspect of the numeral-containing pattern is the specific choice of the numeral " 6 " (used in 2 out of 4 cases) and the fact that the remaining two numerals are represented using letters instead of digits ("three" and "four" instead of 3 and 4). This choice of numerals is quite unexpected as according to previous research on numeral preference in viral headlines, the numerals "6", "3" and "4" are very rarely used in English-language headlines (Safran 2013 URL; Iglikova 2016: 203-211). According to previous research, the numeral "6" is a relatively common choice in Bulgarian headlines (ibid.). This expectation highlights the fact that the present results point to a different approach - namely, one resulting in a lack of a numeral-containing headline among the Bulgarianlanguage headlines.

The fact that such viral content with more than 50 occurrences on Englishlanguage websites has only 4 Bulgarian counterparts is also an interesting aspect of the results from the present case study. It can perhaps be attributed to the 
much smaller scale of Bulgarian-language media (fewer and smaller websites, fewer overall readers, etc.) in comparison with English-language media. Still, taking into consideration the popularity of both the Coca-Cola brand and the McDonald's brand in Bulgaria, one would have expected a more focused and more active online campaign. One striking case to illustrate this is the fact that two websites of the same brand (namely, the American Cosmopolitan.com and the Bulgarian Cosmopolitan.bg) fail to publish such a headline on both platforms - there is an English-language headline on the American website of Cosmopolitan, but not one on the Bulgarian Cosmopolitan.

\section{Conclusion}

The topic of the present article owes its relevance to two main factors - the importance headlines have in online discourse in introducing web content and the role of patterns in making information easier and quicker to process. The article offers a discussion of the specific types and sub-types of patterns employed by both English-language and Bulgarian-language websites in their creation of headlines. It focuses on viral headlines pertaining to one specific topic - the taste of Coca-Cola at McDonald's and bases its deductions on a corpus of 59 headlines taken from both English-language and Bulgarianlanguage websites in an attempt to offer a comparison between the approaches in these two different languages. The analysis of the data demonstrates that the tendency for Bulgarian websites to emulate not only the topics and content of foreign websites (and English-language ones in particular) but also their patterns for creating headlines is quite strong. As far as the English-language headlines are concerned, there seems to be an ongoing tendency among websites for viral content to employ a limited set of patterns for creating headlines. As can be seen from the results of the present study, these patterns are mainly those deemed most successful by researchers in the field of writing for the Web.

\section{Implications}

One specific implication of the present case study entails the interesting deviation from the expected types of headline patterns in terms of the relative rarity of the use of numerals in spite of the fact that the topic itself and the content of the articles are both suitable for listing/enumeration. The fact that out of 54 websites only four chose to include a numeral might be considered as designating a change in the traditional preference for creating listing headlines and heavily employing numerals. 


\section{References:}

Bly 2005: Bly R. W. The Copywriter's Handbook. $3^{\text {rd }}$ edition. New York: Henry Holt and Company, LLC.

Cambridge Online English Dictionary. <https://dictionary.cambridge.org/dictionary/ english/viral $>$ [Accessed 12 June 2017]

Crystal 2001: Crystal D. Language and the Internet. Cambridge: Cambridge University Press.

Hundt, et al. 2007: Hundt M., Nesselhauf N., C. Biewer. Corpus Linguistics and the Web. - In: Hundt M., Nesselhauf N., C. Biewer (Eds.). Corpus Linguistics and the Web. Amsterdam: Rodopi. 1-6.

Iglikova 2016: Iglikova R. What's Your Number? - Numeral Preference in Viral Headlines from 3 Websites. - Lyuboslovie. Shumen: Konstantin Preslavsky University Press, vol. 16, 203-211.

Krug 2005: Krug S. Don't Make Me Think: A Common Sense Approach to Web Usability. $2^{\text {nd }}$ Edition. Berkeley, CA: New Riders.

McGovern et al. 2002: McGovern G., Norton R., C. O'Dowd. The Web Content Style Guide. An Essential Reference for Online Writers, Editors and Managers. London: Financial Times Prentice Hall.

Morkes, Nielsen 1997: Morkes J., J. Nielsen. Concise, SCANNABLE, and Objective: How to Write for the Web. <http://www.nngroup.com/articles/concise-scannable-andobjective-how-to-write-for-the-web/> [Accessed 12 June 2017]

Morville, Rosenfeld 2007: Morville P., L. Rosenfeld. Information Architecture for the World Wide Web. $3^{\text {rd }}$ Edition. USA: O'Reilly Media, Inc. 26-28.

Morrow 2012: Morrow J. 52 Headline Hacks: A “Cheat-Sheet” For Writing Blog Posts That Go Viral. <http://boostblogtraffic.com/headline-hacks/\#> [Accessed 12 June 2017]

Nielsen 1997: Nielsen J. Be Succinct! (Writing for the Web). <http://www.nngroup.com/ articles/be-succinct-writing-for-the-web/> [Accessed 12 June 2017]

Nielsen 1998: Nielsen J. Microcontent: How to Write Headlines, Page Titles, and Subject Lines. $\quad<$ http://www.nngroup.com/articles/microcontent-how-to-write-headlines-pagetitles-and-subject-lines/> [Accessed 12 June 2017]

Nielsen 2000: Nielsen J. Eyetracking Study of Web Readers. <http://www.nngroup.com/ articles/eyetracking-study-of-web-readers/> [Accessed 12 June 2017]

Nielsen 2006: Nielsen J. F-Shaped Pattern for Reading Web Content. <http://www.nngroup. com/articles/f-shaped-pattern-reading-web-content/ $>$ [Accessed 12 June 2017]

Nielsen 2007a: Nielsen J. Blah-Blah Text: Keep, Cut, or Kill? <http://www.nngroup.com/ articles/blah-blah-text-keep-cut-or-kill/> [Accessed 12 June 2017]

Nielsen 2007b: Nielsen J. Long vs. Short Articles as Content Strategy. <http://www. nngroup.com/articles/content-strategy-long-vs-short/> [Accessed 12 June 2017]

Nielsen 2008: Nielsen J. Writing Style for Print vs. Web. <http://www.nngroup.com/ articles/writing-style-for-print-vs-web/> [Accessed 12 June 2017]

Nielsen 2011a: Nielsen J. International Usability: Big Stuff the Same, Details Differ. $<$ http://www.nngroup.com/articles/intarnational-ussability-details-differ/> [Accessed 12 June 2017] 
Nielsen 2011b: Nielsen J. Top 10 Mistakes in Web Design. <http://www.nngroup.com/ articles/top-10-mistakes-web-design/> [Accessed 12 June 2017]

Nielsen 2012: Nielsen J. Usability 101: Introduction to Usability. <http://www.nngroup. com/articles/usability-101-introduction-to-usability/> [Accessed 12 June 2017]

Orendorff 2014: Orendorff A. The Ultimate Copy Checklist: 51 Questions to Optimize Every Element of Your Online Copy. <http://www.copyblogger.com/optimize-onlinecopy/> [Accessed 12 June 2017]

Redish 2012: Redish, J. Letting Go of the Words. USA: Elsevier.

Safran 2013: Safran N. 5 Data Insights into the Headlines Users Click. <https://moz.com/ blog/5-data-insights-into-the-headlines-readers-click> [Accessed 12 June 2017]

Stolley 2011: Stolley K. How to Design and Write Web Pages Today. Greenwood, ABCCLIO, LLC. 